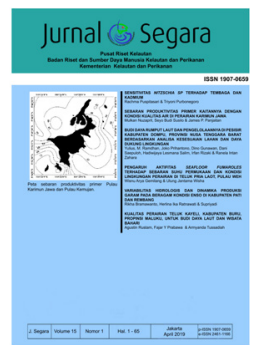

JURNAL SEGARA

http://ejournal-balitbang.kkp.go.id/index.php/segara

ISSN : 1907-0659

e-ISSN : 2461-1166

Nomor Akreditasi: 766/AU3/P2MI-LIPI/10/2016

\title{
KUALITAS PERAIRAN TELUK KAYELI, KABUPATEN BURU, PROPINSI MALUKU, UNTUK BUDI DAYA LAUT DAN WISATA BAHARI
}

\section{WATER QUALITY OF KAYELI BAY, BURU DISTRICT, MALUKU PROVINCE FOR MARINE TOURISME AND AQUACULTURE}

\author{
Agustin Rustam, Fajar Yudi Prabawa \& Armyanda Tussadiah \\ Pusat Riset Kelautan, BRSDM Kelautan \& Perikanan, \\ Kementerian Kelautan \& Perikanan Republik Indonesia
}

Diterima: 22 Februari 2015; Diterima Setelah Perbaikan: 11 Januari 2019; Disetujui Terbit: 30 Maret 2019

\begin{abstract}
ABSTRAK
Kualitas perairan merupakan salah satu faktor penting dalam mendukung usaha budi daya laut dan wisata bahari yang umumnya dilakukan di sebuah perairan teluk, seperti Teluk Kayeli yang terletak di Pulau Buru. Penelitian ini bertujuan untuk menganalisis kondisi perairan Teluk Kayeli yang dimanfaatkan sebagai lokasi kegiatan budi daya laut dan wisata bahari. Pengambilan sampel air dilakukan dengan menggunakan metode survei, dengan penentuan titik sampling secara sistematis di seluruh bagian dalam teluk pada Oktober 2014. Hasil penelitian menunjukkan bahwa kualitas perairan di Teluk Kayeli masih sesuai baku mutu. Sebanyak 18 jenis fitoplankton dan 8 jenis zooplankton yang ditemukan. Kelimpahan rata-rata fitoplankton $51 \mathrm{sel} / \mathrm{L}$ dengan kelimpahan tertinggi jenis Chaetoceros decipiens. Berdasarkan analisis kualitas perairan Teluk Kayeli dinilai sesuai untuk budi daya keramba jaring apung dan wisata bahari, dengan nilai nitrat 0,006 mg/L, DO (Dissolved Oxygen) $5,89 \mathrm{mg} / \mathrm{L}$, salinitas 33,26 PSU dan turbiditas 0,23 NTU. Hasil penelitian ini tidak mengukur kandungan logam berat dalam perairan sehingga disarankan agar dilakukan pengukuran logam berat terkait dengan masih adanya usaha penambangan yang membuang limbah ke sungai. Berdasarkan analisis kualitas perairan penelitian ini, Teluk kayeli sesuai untuk budi daya jaring apung maupun wisata bahari sehingga diperlukan infrastruktur ramah lingkungan yang mendukung, serta kajian daya dukung Teluk Kayeli untuk dua kegiatan tersebut.
\end{abstract}

Kata kunci: Kualitas Air, budi daya Laut, Teluk Kayeli, Pulau Buru.

\begin{abstract}
Water quality is one the factors to support marine aquaculture and marine tourism which is commonly done in the bay, such as in the Kayeli Bay located on Buru Island. Information about the water quality of Kayeli Bay has not been widely known. For that purpose, research aimed to analyze the water conditions of Kayeli Bay which is used as the location of marine aquaculture activities and marine tourism. field sampling was used survey method with systematic sampling point at all parts of the bay conducted in October 2014. Results show that water quality in the Kayeli Bay is still in accordance to the quality standards. A total of 18 types of phytoplankton and 8 types of zooplankton were found was an average abundance of 51 cells $/ L$ phytoplankton with the highest abundance of Chaetoceros decipiens. Based on the water quality analysis, Kayeli Bay is considered suitable for the cultivation of floating net cages and marine tourism, value of nitrate $0.006 \mathrm{mg} / \mathrm{L}$, dissolved oxygen (DO) $5.89 \mathrm{mg} / \mathrm{L}$, salinity 33.26 PSU and turbidy 0.23 NTU. The results of this research without a measurement heavy metal in the water, suggested to concern related to the existence of mining business that dumps waste into the river. Water quality of Kayely Bay suitable for the cultivation of floating net and marine tourism and its need Environmentally friendly infrastructure to supporting as well as study of carrying capacity of Kayeli Bay for the two activities.
\end{abstract}

Keywords: Buru Island, Kayeli Bay, Water quality, aquaculture.

Corresponding author:

Jl. Pasir Putih I Ancol Timur, Jakarta Utara 14430. Email: agustin.rustam@kkp.go.id 


\section{PENDAHULUAN}

Teluk Kayeli yang berada di sebelah timur Pulau Buru merupakan teluk terbesar di pulau ini termasuk dalam kawasan lumbung ikan di Indonesia timur. Teluk ini memiliki potensi besar di bidang perikanan tangkap maupun perikanan budi daya. Teluk Kayeli dengan keberadaan ekosistem pesisir yang lengkap yaitu terumbu karang, mangrove dan padang lamun (Wouthuyzen et al., 2002) dapat menjadi daerah wisata bahari dan daerah budi daya laut baik untuk rumput laut atau Keramba Jaring Apung (KJA). Diperkuat dengan penelitian Haris (2003) di Teluk Kayeli yang mendapatkan daerah yang sangat sesuai untuk KJA seluas $43,882 \mathrm{~km}^{2}$ yang berada di sekitar perairan desa Malea, Kayeli, Sanleko dan Seith, sedangkan untuk wisata bahari khususnya wisata pantai seluas 198,938 ha yang sangat sesuai beada di desa Namlea, Kayeli dan Seith.

Pada 2012 terjadi peristiwa kematian massal ikan di Teluk Kayeli yang disebabkan oleh adanya pencemaran perairan yang berasal dari limbah penambangan emas Gunung Botak terutama merkuri (Siwalima, 2012). Hal ini diperkuat masih adanya penambangan emas yang dilakukan di Gunung Botak, di Pulau Buru yang masih menggunakan merkuri, limbah pencucian emas mengalir ke Teluk Kayeli yang berdampak ke perairan Teluk Kayeli sendiri bahkan sampai ke Laut Maluku (Khow, 2014). Mengingat perairan Indonesia Timur sebagai lumbung ikan nasional maka diperlukan penelitian mengenai kualitas perairan terkait dengan perikanan tangkap maupun budi daya.

Penelitian mengenai kualitas perairan baik untuk kelayakan kehidupan biota ataupun wisata bahari dan lainnya sangat penting dilakukan terutama secara terus menerus seperti di Teluk Kayeli. Daerah wisata bahari yang terkenal seperti Wakatobi dengan kondisi perairan yang masih sesuai namun memerlukan pemantauan secara time series terkait dengan parameter suhu dan salinitas (Rustam et al., 2014). Mengingat aktivitas penambangan liar yang masih ada dapat mengakibatkan menurunnya kualitas perairan, seperti parameter nutrient, parameter fisika, parameter biologi maupun parameter kimia yang terukur di beberapa titik sampling yang terpengaruh langsung atau tidak langsung dengan aktivitas penambangan. Penelitian ini bertujuan menginventarisasi kondisi perairan Teluk Kayeli terkini untuk dianalisis kelayakannya menurut kesesuaian baku mutu lingkungan perairan laut baik untuk kehidupan biota maupun wisata bahari dan standar kesesuaian budi daya keramba jaring apung.

\section{METODE PENELITIAN}

Pengukuran parameter air dan analisis laboratorium sampel air laut dilaksanakan pada Oktober 2014, dengan lokasi penelitian di Teluk Kayeli, Kabupaten Buru, Propinsi Maluku. Metode pengambilan sampel dilakukan secara purposive sampling yang mewakili lokasi penelitian yang merupakan lokasi tempat budi daya jaring apung, jarak dari daratan serta kedalaman perairan. Pengukuran kualitas perairan in situ dengan menggunakan multiparameter dari muara sungai sampai ke arah laut pada lapisan permukaan dan pengambilan sampel air untuk analisis laboratorium pada 12 titik stasiun (Gambar 1).

Parameter yang terukur secara in situ menggunakan alat multiparameter merk HORIBA U-52 berjumlah 9 parameter, yaitu $\mathrm{pH}$, DO (Dissolved Oxygen), konduktivitas, turbiditas, suhu, salinitas, TDS (Total Dissolved Suspended), sigma-t dan ORP (Oxydation Reduction Potential) pada dua lapisan kedalaman yaitu permukaan $(<1 \mathrm{~m})$ dan kedalaman 5 $\mathrm{m}$. Parameter nutrien yaitu nitrat dan fosfat serta plankton diambil pada kedalaman 5 meter dianalisis di Laboratorium Kualitas Air pada Pusat Penelitian Laut Dalam - LIPI, Ambon. Parameter yang diamati dikelompokkan: parameter fisika (suhu, konduktivitas, turbiditas dan TDS), parameter kimia $(\mathrm{pH}$, salinitas, sigma-t, ORP dan DO), parameter nutrien (nitrat dan fosfat) serta parameter biologi (plankton). Sampel plankton diperoleh dengan mengambil contoh air laut yang menggunakan botol Nansen sebanyak 20 liter pada kedalaman $\sim 5 \mathrm{~m}$, kemudian disaring menggunakan plankton net (mesh size $40 \mu \mathrm{m}$ ). Setelah disaring, sampel air dimasukkan dalam botol sampel dengan volume $100 \mathrm{~mL}$ lalu diteteskan larutan Lugol 1\% sebanyak 4 tetes (Sahu et al., 2012). Kelimpahan plankton dihitung dengan menggunakan metode Sedgwick rafter Cell (APHA, 2005). plankton diidentifikasi menggunakan mikroskop perbesaran 100X. Identifikasi plankton mengacu pada Yamaji (1966).

Metoda analisis data secara deskriptif dengan MS Excell 2007 menggambarkan kondisi kualitas perairan saat ini. Variasi parameter fisika-kimia perairan antar stasiun penelitian dianalisis dengan menggunakan pendekatan analisis statistik perubah ganda yang didasarkan pada Analisis Komponen Utama (Principal Component Analysis, PCA) (Legendre \& Legendre, 1983). Selain itu analisis PCA dengan model logaritma nya digunakan untuk menyederhanakan set data dengan dimensi yang tinggi menjadi dimensi yang lebih sederhana untuk analisis data, visualisasi, ekstraksi dan kompresi/ pemampatan data (Raiko et al., 2007; Illin \& Raiko, 2010). Keuntungan analisis ini dapat menyederhanakan data dan mengklasifikasi data lebih cepat (Blei, 2008). 

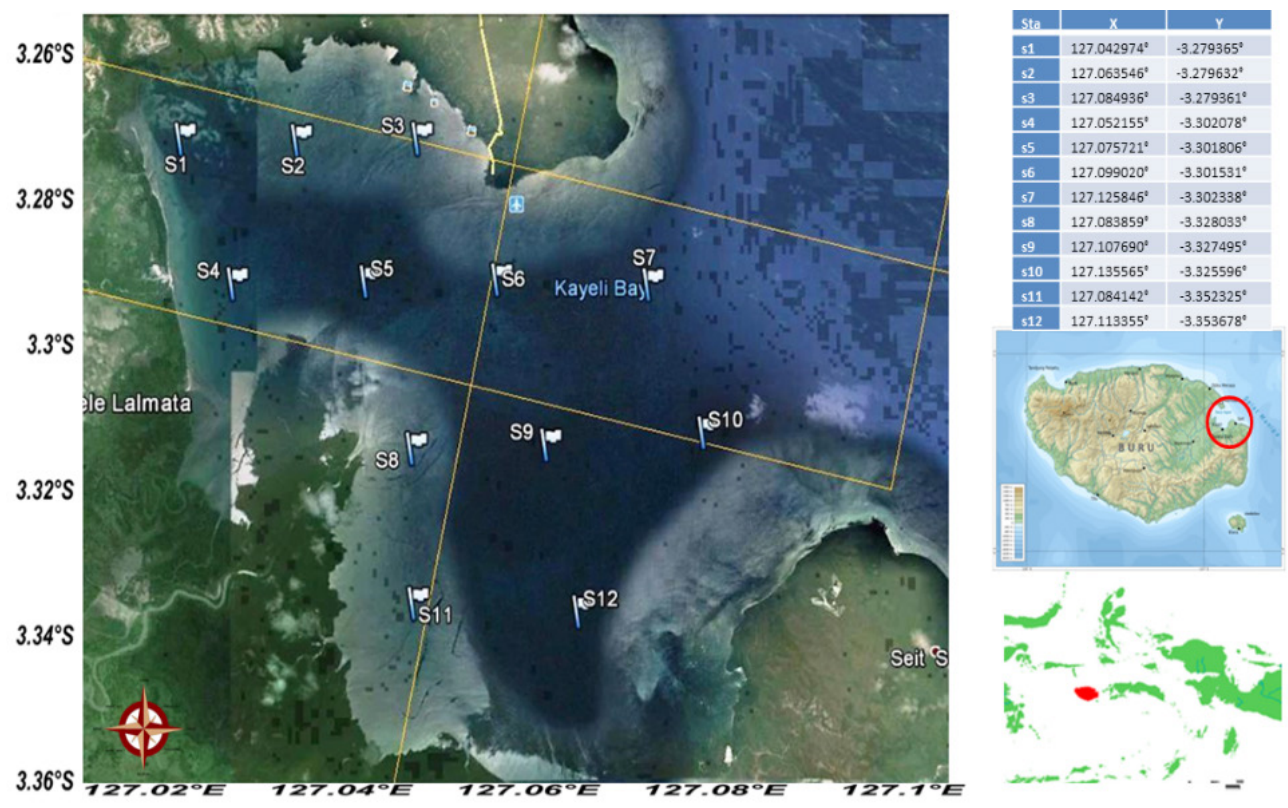

Gambar 1. Peta lokasi penelitian di Teluk Kayeli, Pulau Buru, Oktober 2014.

Sehingga dapat ditentukan peran parameter pada titik sampling tertentu. Analisis statistik ini dilakukan dengan menggunakan XLStat 2013 (evaluation).

\section{HASIL DAN PEMBAHASAN}

Nilai rerata hampir semua parameter yang terukur dalam dua lapisan kedalaman secara in situ tidak ada perbedaan yang signifikan (Tabel 1). Nilai yang berbeda terlihat pada parameter fisika turbiditas lebih besar di kedalaman $5 \mathrm{~m}(0,227 \mathrm{NTU})$ dibandingkan di lapisan permukaan $(0,09$ NTU). Parameter kimia DO pada lapisan permukaan $(6,4 \mathrm{mg} / \mathrm{L})$ lebih tinggi dibandingkan kedalaman $5 \mathrm{~m}(5,89 \mathrm{mg} / \mathrm{L})$.

Tabel 1.

Hasil statistik deskriptif Teluk Kayeli pada Oktober 2014

\begin{tabular}{|c|c|c|c|c|c|c|}
\hline \multirow[t]{3}{*}{ Parameter } & \multirow{2}{*}{\multicolumn{2}{|c|}{ Baku mutu }} & \multicolumn{4}{|c|}{ Kedalaman } \\
\hline & & & \multirow{2}{*}{$\begin{array}{l}5 \mathrm{~m} \\
\text { Rerata }\end{array}$} & \multirow{2}{*}{ St dev } & \multicolumn{2}{|c|}{ Permukaan } \\
\hline & Biota** & Wisata Bahari* & & & Rerata & St dev \\
\hline \multicolumn{7}{|l|}{ Fisika } \\
\hline Suhu $\left({ }^{\circ} \mathrm{C}\right)$ & $28-32$ & Alami 3(c) & 27,51 & 0,185 & 27,76 & 0,359 \\
\hline Konduktivitas $(\mathrm{mS} / \mathrm{cm})$ & - & - & 53,19 & 0,202 & 53,2 & 0,741 \\
\hline Turbiditas (NTU) & $<5$ & 5 & 0,23 & 0,754 & 0,09 & 0,285 \\
\hline Total Dissolved Solid [TDS] (g/L) & - & - & 31,92 & 0,117 & 31,9 & 0,450 \\
\hline \multicolumn{7}{|l|}{ Kimia } \\
\hline Dissolved Oxygen [DO] (mg/L) & $>5$ & $>5$ & 5,89 & 0,311 & 6,4 & 0,045 \\
\hline $\mathrm{pH}$ & $7-8,5$ & $7-8,5(d)$ & 7,96 & 0,173 & 7,95 & 0,018 \\
\hline Salinitas (PSU) & $28-35$ & alami 3(e) & 33,26 & 0,093 & 33,05 & 0,381 \\
\hline Specific gravity (sigma t) & - & - & 21,38 & 0,108 & 21,14 & 0,288 \\
\hline Oxidation Reduction Potential [ORP] (mV) & - & - & 96,09 & 17,958 & 95 & 13,768 \\
\hline \multicolumn{7}{|l|}{ Nutrien } \\
\hline Fosfat $\left[\mathrm{PO}_{4}\right] \mathrm{mg} / \mathrm{L}$ & 0,015 & 0,005 & 0,002 & - & - & \\
\hline $\begin{array}{l}\text { Nitrat }\left[\mathrm{NO}_{3}\right] \mathrm{mg} / \mathrm{L} \\
\text { Biologi }\end{array}$ & $0,9-3,2$ & 0,008 & 0,006 & 0,003 & - & - \\
\hline Fitoplankton (sel/L) & - & - & 51 & 65,35 & - & - \\
\hline Zooplankton (ind/L) & - & - & 3 & 3,41 & - & - \\
\hline \multicolumn{7}{|l|}{$\begin{array}{l}\text { C= diperbolenkan terad } \\
\text { d= diperbolehkan terjadi } \\
\text { e= diperbolehkan teriadi }\end{array}$} \\
\hline
\end{tabular}




\section{Parameter Fisika}

Kisaran suhu pada lapisan permukan adalah $27,31-28,45^{\circ} \mathrm{C}$ dengan rata-rata $27,51 \pm 0,185^{\circ} \mathrm{C}$ dengan sebaran spasial suhu permukaan lebih tinggi pada bagian utara di dalam teluk dan lebih rendah di bagian selatan dan luar teluk (Tabel 1 dan Gambar 2). Papalia (2013) mendapatkan nilai suhu sebesar $27,23 \pm 0,31^{\circ} \mathrm{C}$ di lokasi yang sama pada tahun 2012. Nilai suhu pada kedua kedalaman yang berbeda merupakan suhu alami sesuai yang sesuai untuk budi daya laut jaring apung ataupun wisata bahari yaitu berkisar antara $27-29^{\circ} \mathrm{C}$.

Nilai total padatan terlarut (Total Dissolved Solid $=$ TDS) pada semua stasiun pengukuran pada lapisan permukaan adalah $31,9 \pm 0,45 \mathrm{~g} / \mathrm{L}$ dan lapisan $5 \mathrm{~m}$ sebesar $31,92 \pm 0,117 \mathrm{~g} / \mathrm{L}$. Besarnya nilai terlihat seragam pada lapisan $5 \mathrm{~m}$ dengan nilai standar deviasi yang lebih rendah dibandingkan lapisan permukaan. Namun ada kecenderungan nilai TDS meningkat mendekati daratan pada lapisan permukaan (Gambar 2). Total padatan yang diukur merupakan padatan terlarut yang berada dalam badan air yang tidak disaring. Yang terukur dengan alat adalah semua senyawa-senyawa anorganik maupun organik yang berada dalam badan air terutama ion-ion anorganik (garam). TDS terukur mendekati nilai salinitas dikarenakan perairan yang yang diukur adalah perairan laut yang secara visual sangat jernih dan bebas dari partikel-partikel dari sungai tidak seperti di Jawa.
Nilai kekeruhan atau turbiditas yang terukur berkisar antara 0 - 2,5 NTU dengan rata-rata 0,23 $\pm 0,754$ NTU pada kedalaman $5 \mathrm{~m}$ dapat dikatakan peraiaran Teluk Kayeli jernih (Tabel 1). Nilai kekeruhan di lapisan permukaan umumnya nihil menjauhi daratan (Gambar 2). Menurut Radiarta et al. (2006); Affan, (2012); Anggraini et al, (2018) maupun KMNLH No 51 Tahun 2014 (baku mutu yang digunakan dalam penelitian ini) bahwa untuk kehidupan biota maupun wisata bahari nilai kekeruhan perairan < 5 NTU. Berdasarkan rekomendasi ini maka potensi perairan Teluk Kayeli sesuai dengan baku mutu tersebut karena rata-rata dari kedua lapisan kedalaman adalah < 5 NTU, sehingga masih dapat dimanfaatkan sebagai lahan budi daya KJA, daerah hidup biota maupun wisata bahari. Pentingnya perairan yang rendah kekeruhannya terkait dengan proses fotosintesis yang memerlukan cahaya yang dapat masuk ke dalam perairan dan berhubungan erat dengan produser dalam perairan, baik itu fitoplankton, seagrass (lamun) ataupun terumbu karang (coral reef). Semua akan berhubungan dengan rantai makanan sampai ke biota yang ekonomis seperti ikan, kerang dan rajungan.

\section{Parameter Kimia}

Parameter kualitas kimia perairan yang terukur meliputi $\mathrm{pH}$, salinitas, DO, specific gravity dan ORP (Tabel 1 dan Gambar 3). Nilai pH baik pada lapisan permukaan memilki nilai yang sama $(7,91-7,97)$ berbeda dengan kedalaman $5 \mathrm{~m}(7,5-8,16)$. Nilai
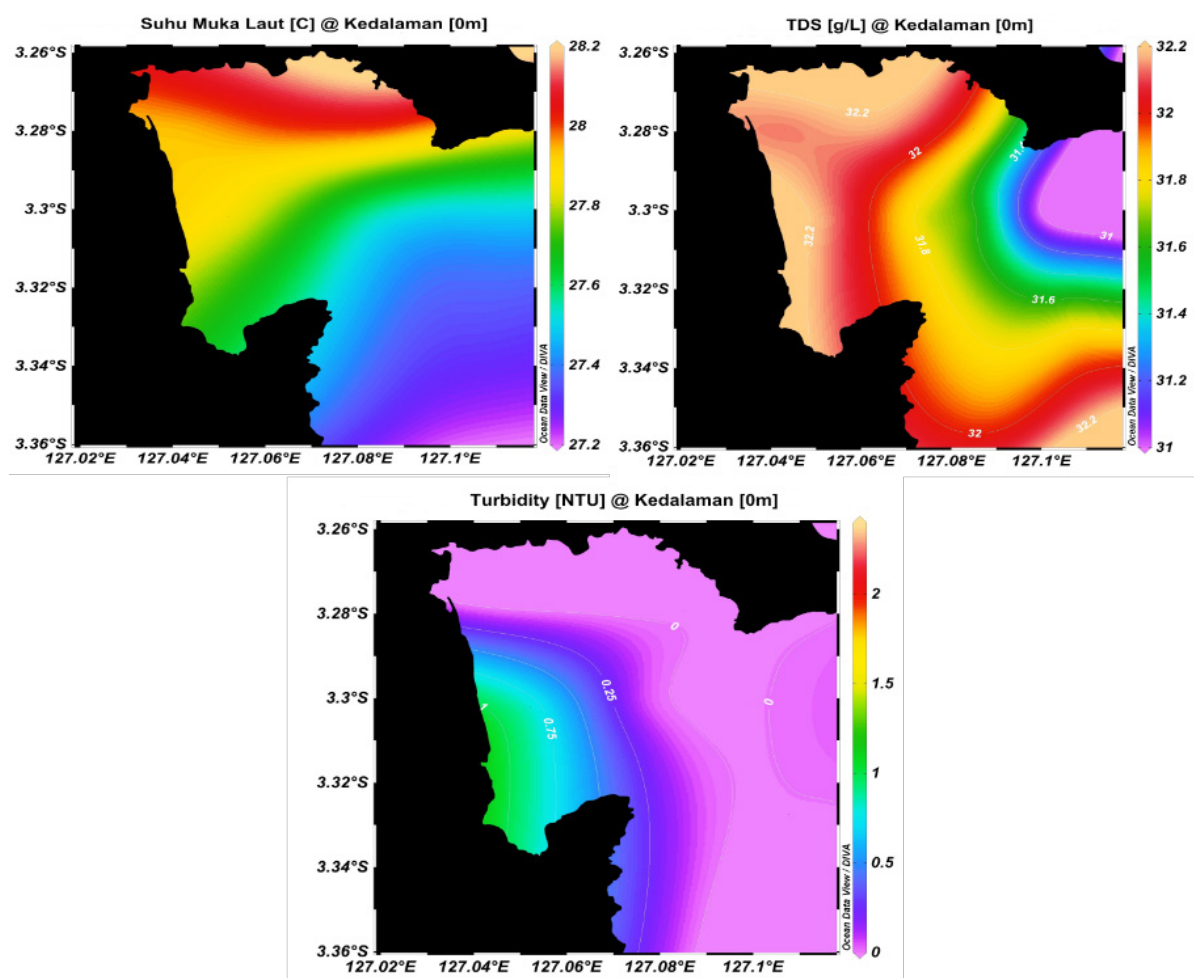

Gambar 2. Sebaran parameter suhu, TDS dan turbidity (turbiditas) pada lapisan permukaan Teluk Kayeli, Oktober 2014. 
$\mathrm{pH}$ yang didapat lebih tinggi pada pengukuran 2012 yang berkisar 7-7,6 (Papalia, 2013). Kisaran pH ini merupakan kisaran $\mathrm{pH}$ yang sesuai dengan baku mutu air laut KMNLH No. 51 Tahun 2004 baik untuk wisata bahari maupun biota laut atau budi daya yaitu 7-8,5. Berdasarkan sebaran spasial pada lapisan permukaan nilai $\mathrm{pH}$ cenderung lebih tinggi pada bagian utara Teluk Kayeli. Nilai terendah pH di kedalaman 5 m ST2 dibandingkan stasiun lainnya dapat disebabkan adanya masukan air tawar dari muara sungai Namlea. Selain itu dapat juga disebabkan limbah dari penambangan emas di Gunung Gorgorea yang terakumulasi di sedimen cukup tinggi sehingga mempengaruhi $\mathrm{pH}$ di perairan dangkal. Tingginya nilai merkuri di sedimen Teluk Kayeli dan Sungai Wae Apu berdasarkan hasil penelitian 2011 sampai dengan 2013 mencapai 3 $\mathrm{mg} / \mathrm{kg}$ lumpur, (Teluk Kayeli) dan mencapai $9 \mathrm{mg} /$ $\mathrm{kg}$ lumpur (Sungai Wae Apu), padahal ambang batas merkuri 0,02 mg/kg (Male, 2014). Namun berdasarkan baku mutu (Tabel 1) nilai $\mathrm{pH}$ perairan masih sesuai baik untuk biota maupun wisata bahari. Namun keberadaan merkuri dalam lumpur yang tinggi diperlukan pengukuran merkuri dalam badan air dalam penelitian selanjutnya.

Rata-rata pengukuran oksigen terlarut lapisan permukaan $(6,4 \pm 0,045 \mathrm{mg} / \mathrm{L})$ dan kedalaman 5 $\mathrm{m}(5,89 \pm 0,311 \mathrm{mg} / \mathrm{L})$ menunjukkan perairan tidak tercemar atau tingkat kesuburan yang tinggi. Lee et al, (1978) menggolongkan nilai oksigen terlarut atas empat kelompok yaitu tidak tercemar $(>6,5 \mathrm{mg} / \mathrm{L})$, tercemar ringan $(4,5-6,5 \mathrm{mg} / \mathrm{L})$, tercemar sedang $(2,0-$ $4,5 \mathrm{mg} / \mathrm{L}$ ) dan tercemar berat ( $<2,0 \mathrm{mg} / \mathrm{L}$ ). Sedangkan berdasarkan bakumutu yang dipakai untuk budi daya KJA nilai oksigen terlarut cukup sesuai sedangkan untuk wisata bahari sudah sesuai.

Berfluktuasinya DO dapat dijelaskan bahwa konsentrasi dan distribusi oksigen terlarut (DO) selain ditentukan oleh suhu perairan dan proses pengadukan juga ditentukan oleh proses biologis yang mengontrol tingkat konsentrasi dan pembebasan oksigen. Misalnya terjadi penumpukan bahan organik yang berasal dari pakan ikan budi daya KJA dapat mengakibatkan menipisnya oksigen terlarut dalam air yang akibat fatalnya dapat mengakibatkan kematian massal dari ikan budi daya. Hal ini disebabkan oksigen terpakai oleh detrivor untuk mengurai bahan organik menjadi bahan inorganik. Makin tinggi suhu, salinitas dan tekanan gas-gas, menyebabkan kandungan oksigen makin berkurang. Selain itu faktor fisik perairan seperti arus dan gelombang laut ikut mempengaruhi kecepatan oksigen memasuki dan terdistribusi dalam perairan (Welch, 1980).

Salinitas di lokasi penelitian termasuk salinitas alami, rata-rata pada lapisan permukaan sebesar $33,05 \pm 0,381$ PSU (Gambar 4) maupun di kedalaman 5 m sebesar 33,26 $\pm 0,093$ PSU terlihat salinitas di seluruh stasiun pengamatan merupakan salinitas air laut.

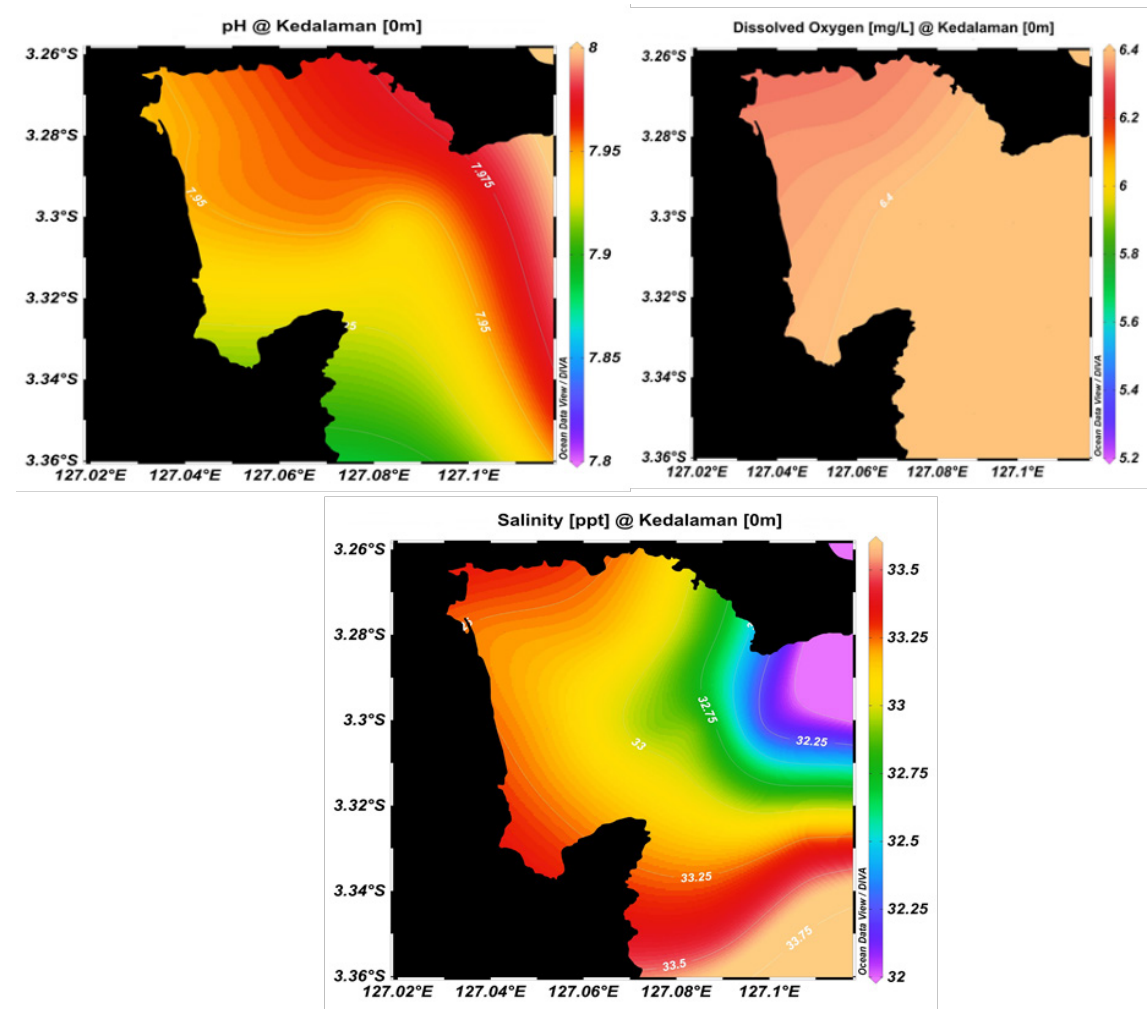

Gambar 3. Sebaran parameter pH, DO dan salinitas pada lapisan permukaan di Teluk Kayeli Oktober 2014. 
Salinitas permukaan dalam kisaran 33-2,1-33,4 PSU terlihat adanya fluktuasi berdasarkan Gambar 3, nilai salinitas menurun ke luar teluk dengan nilai terendah di bagian utara dari mulut teluk (Gambar 3). Sedangkan nilai salinitas kedalaman $5 \mathrm{~m}$ terlihat stabil dengan rendahnya standar deviasi $(0,093)$ dan kisaran 33,133,4 PSU (Tabel 1). Kaitan salinitas dalam kehidupan biota akuatik tergantung dari kemampuan biota berosmoregulasi, yaitu kemampuan biota mengatur keseimbangan perbedaan antara larutan garam dalam tubuh dengan lingkungan tempat hidupnya. Nilai salinitas baik kedalaman permukaan maupun kedalaman $5 \mathrm{~m}$ berdasarkan baku mutu yang dipakai sangat sesuai untuk budi daya KJA dan wisata bahari, selain itu juga sesuai untuk pertumbuhan ekosistem karang, lamun maupun mangrove. Keberadaan mangrove di Teluk Kayeli berdasarkan penelitian Wouthuyzen et al. (2002) dengan menggunakan citra tahun 1986, 1992 dan 1996 masih dalam keadaan bagus dengan luas mangrove yang hampir tidak berubah banyak (sekitar 3.525 ha).

Nilai Oxidation Reduction Potential (ORP) pada lapisan permukaan sebesar $95 \pm 13,768 \mathrm{mv}$ sedangkan

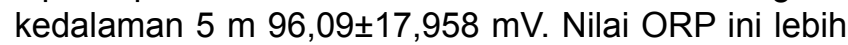
rendah dibandingkan yang didapat Sukma et al. (2015) pada air pantai sebesar $142 \mathrm{mV}$ dan di Danau Tondano 166 - 200 mV (Urbasa et al., 2015). Nilai ORP dalam suatu perairan dapat menunjukkan kesehatan suatu perairan, jika nilai ORP tinggi maka perairan dikatakan sehat karena mampu membersihkan diri dari bahan kontaminan seperti bahan organik melalui proses dekomposisi dengan nilai DO yang tinggi, begitu juga sebaliknya nilai ORP rendah dikatakan peraiaran tidak sehat dengan nilai DO juga rendah dan dapat menurunkan nilai pH perairan (Horne \& Goldman, 1994; Edelman, 1997).

\section{Konsentrasi nutrien}

Parameter nitrat dan fosfat yang diukur hanya pada kedalaman $5 \mathrm{~m}$. Besaran nilai nitrat adalah $0,006 \pm 0,003 \mathrm{mg} / \mathrm{L}$ dan fosfat $0,005 \pm 0,002 \mathrm{mg} / \mathrm{L}$ (Gambar 4). Berdasarkan bakumutu (Tabel 1), nilai nitrat dan fosfat masih di bawah baku mutu sehingga dapat dikatakan sesuai untuk kehidupan biota laut (budi daya) dan wisata bahari. Namun nilai ini rendah berdasarkan bakumutu yang diambil dari beberapa literatur khusus biota budi daya jaring apung misalnya budi daya ikan kerapu (Radiarta et al., 2006; Affan, 2012; Anggraini et al., 2018).

Berdasarkan hasil penelitian konsentrasi nutrient (Gambar 4), nilai konsentrasi terlihat untuk nitrat nilai tertinggi berada di ST8 yang berada di bagian dalam teluk (pesisir) sedangkan nilai fosfat umumnya tinggi di bagian tengah teluk (ST5 dan ST9). Nilai nutrien perairan di lokasi penelitian umumnya rendah dibandingkan baku mutu hal ini dapat disebabkan

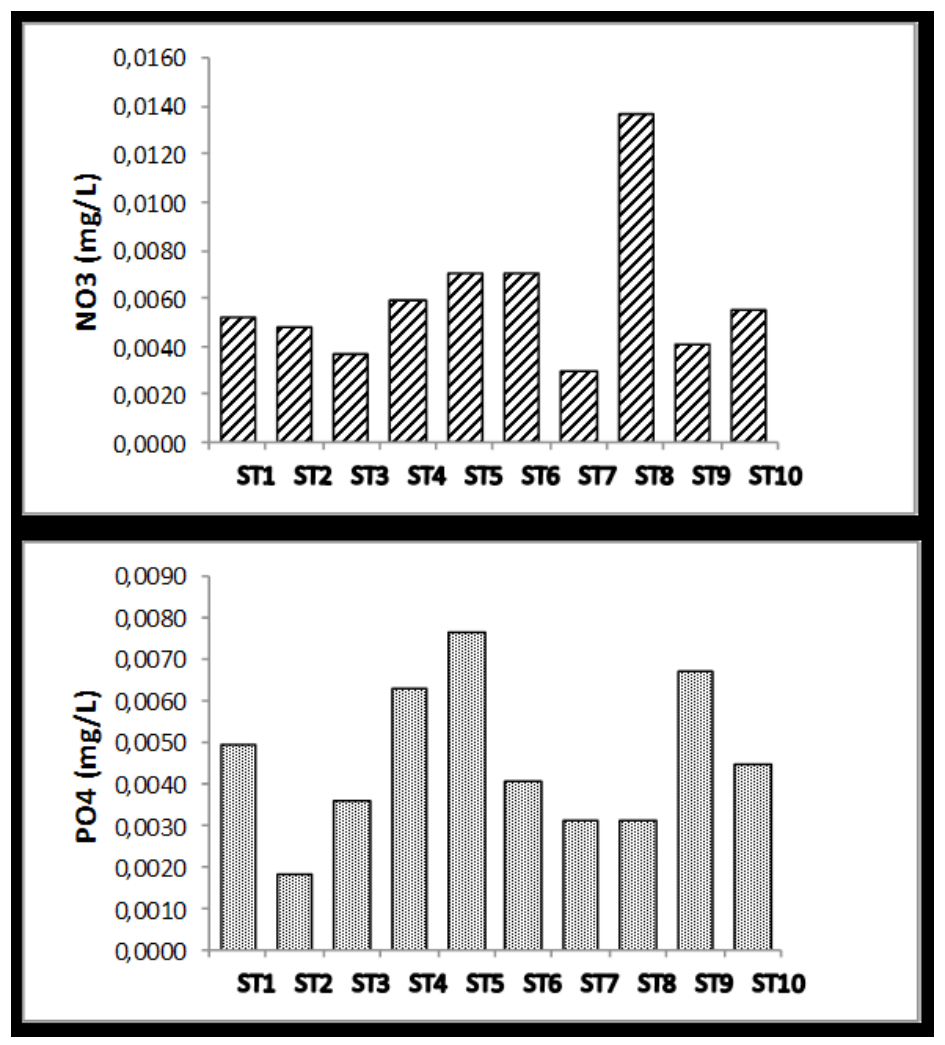

Gambar 4. Sebaran parameter nitrat $\left(\mathrm{NO}_{3}\right)$ dan fosfat $\left(\mathrm{PO}_{4}\right)$ pada lapisan kedalaman $5 \mathrm{~m}$ di Teluk Kayeli Oktober 2014. 
masih sedikit masukan dari daratan seperti limbah pertanian atau domestik lainnya.

\section{Kualitas Biologi Perairan}

Kualitas biologi perairan yang diukur dalam penelitian ini adalah fitoplankton dan zooplankton, fitoplankton ditemukan 18 jenis dari dua kelas (Bacillariophyceae 10 jenis dan Dinophyceae 8 jenis), zooplankton ditemukan 8 jenis (Crustaceae 4 jenis dan larva biota lainnya 4 jenis). Kelimpahan ratarata fitoplankton sebesar $51 \mathrm{sel} / \mathrm{L}\left(51.000 \mathrm{sel} / \mathrm{m}^{3}\right)$ dan zooplankton 3 individu/L (3.000 ind $\left./ \mathrm{m}^{3}\right)$. Jumlah spesies zooplankton yang ditemukan lebih rendah dibandingkan dengan zooplankton yang ditemukan di perairan pesisir Morella, Maluku Tengah (Mulyadi \& Radjab, 2015) dan lebih tinggi dibandingkan di perairan Jailolo, Halmahera Barat (Yuliana, 2014). Kelimpahan tertinggi fitoplankton pada jenis Chaetoceros decipiens di stasiun 4 sebesar $177 \mathrm{sel} / \mathrm{L}$. Kelimpahan penelitian ini lebih tinggi dibandingkan di Morella (rata-rata 890 ind/m3) dan dan lebih rendah dibandingkan di Jailolo (rata-rata untuk zooplankton (Yuliana, 2014; Mulyadi \& Radjab, 2015).

Nilai indeks keanekaragaman tertinggi fitoplankton dan zooplankton terdapat di ST7, indeks keseragaman fitoplankton di ST5 dan zooplankton di ST9. Nilai indeks dominansi fitoplankton dan zooplankton tertinggi di ST10 dan ST7 (Tabel 2). Nilai indeks keanekaragaman dan dominansi hasil penelitian ini lebih tinggi dibandingkan di perairan Jailolo, Halmahera Barat dan lebih rendah untuk indeks keseragaman (Yuliana, 2014).

Hasil penelitian menunjukkan bahwa komunitas baik fitoplankton maupun zooplankton dalam kriteria kestabilan sedang (Lee et al., 1978). Penelitian mengenai parameter biologi mengenai plankton untuk analisis kualitas perairan terkait erat dengan produser atau sumber makanan bagi biota lainnya. Jika kondisi komunitas plankton baik maka keberlanjutan rantai makanan biota di atasnya akan baik juga, sehingga dapat dikatakan perairan tersebut sesuai untuk kehidupan biota laut.

\section{Analisis karakteristik habitat}

Analisa karakteristik habitat dilakukan dengan analisa statitik PCA, agar dapat diketahui dari semua parameter yang terukur parameter mana yang berperan di daerah ini (Gambar 5). Variasi kondisi antar stasiun dianalisa dan dideterminasi berdasarkan sebaran 9 parameter karakteristik ditunjukkan pada Gambar 5. Hasil analisis PCA dari matriks ragam peragam menunjukkan bahwa informasi yang terjelaskan menggambarkan hubungan antara parameter dalam hubungannya dengan sebaran spasial stasiun penelitian dijelaskan pada ketiga sumbu utama (F1, F2 dan F3) sebesar 73,69 \%.

Korelasi antar parameter fisiko-kimiawi pada Gambar 5 panel atas dilihat berdasarkan parameter sebesar 73,69 \%, menunjukkan bahwa parameter suhu, konduktivitas, fosfat dan turbiditas berperan besar pada sumbu positif 1 maupun sumbu 2 . Oksigen terlarut (DO), salinitas dan sigma t berperan besar pada sumbu 1 negatif dan sumbu 2 positif yang berkorelasi negatif dengan ORP. Korelasi signifikan ditunjukkan antar parameter suhu dengan konduktivitas yang berkorelasi positif dengan R2 sebesar 0,812. Secara sebaran spasial stasiun pengamatan pada sumbu 1 dan 2 terlihat pada Gambar 5 panel bawah. Stasiun Muara Namlea dicirikan dengan konduktivitas dan TDS yang cukup tinggi berada dekat pantai berkorelasi positif dengan R2 sebesar 0,939.

\section{Analisis Kesesuaian Teluk Kayeli sebagai Budi daya KJA dan Wisata Bahari}

Kriteria kesesuaian parameter perairan untuk budi daya ikan laut dalam KJA (Radiarta et al., 2006; Affan, 2012; Anggraeni et al., 2018 ) untuk parameter yang

Tabel 2.

Nilai indeks keanekaragaman, keseragaman dan dominansi fitoplankton dan zooplankton di Teluk Kayeli Oktober 2014

\begin{tabular}{lllllll}
\hline stasiun & \multicolumn{2}{c}{$\begin{array}{l}\text { Indeks Keanekaragaman } \\
\text { Fitoplankton }\end{array}$} & Zooplankton & \multicolumn{2}{c}{ Indeks Keseragaman } & \multicolumn{2}{c}{ Indeks Dominansi } \\
& Fitoplankton & Zooplankton & Fitoplankton & Zooplankton \\
\hline ST1 & 1,5112 & 0,7963 & 0,843416 & 0,724834 & 0,449072 & 0,212316 \\
ST2 & 0 & 0,693147 & - & 1 & 0 & 0,240227 \\
ST3 & 1,2792 & 0 & 0,794798 & - & 0,372253 & 0 \\
ST4 & 0,7347 & 1,21489 & 0,377544 & 0,876358 & 0,114186 & 0,383208 \\
ST5 & 1,3108 & - & 0,945531 & - & 0,439529 & - \\
ST6 & 0 & 0 & - & - & 0 & 0 \\
ST7 & 1,8712 & 1,277034 & 0,851602 & 0,921185 & 0,416132 & 0,414531 \\
ST8 & 0 & - & - & - & 0 & - \\
ST9 & 0,858 & 1,039721 & 0,478855 & 0,946395 & 0,187796 & 0,36034 \\
ST10 & 1,4681 & - & 0,912207 & - & 0,451992 & - \\
\hline
\end{tabular}



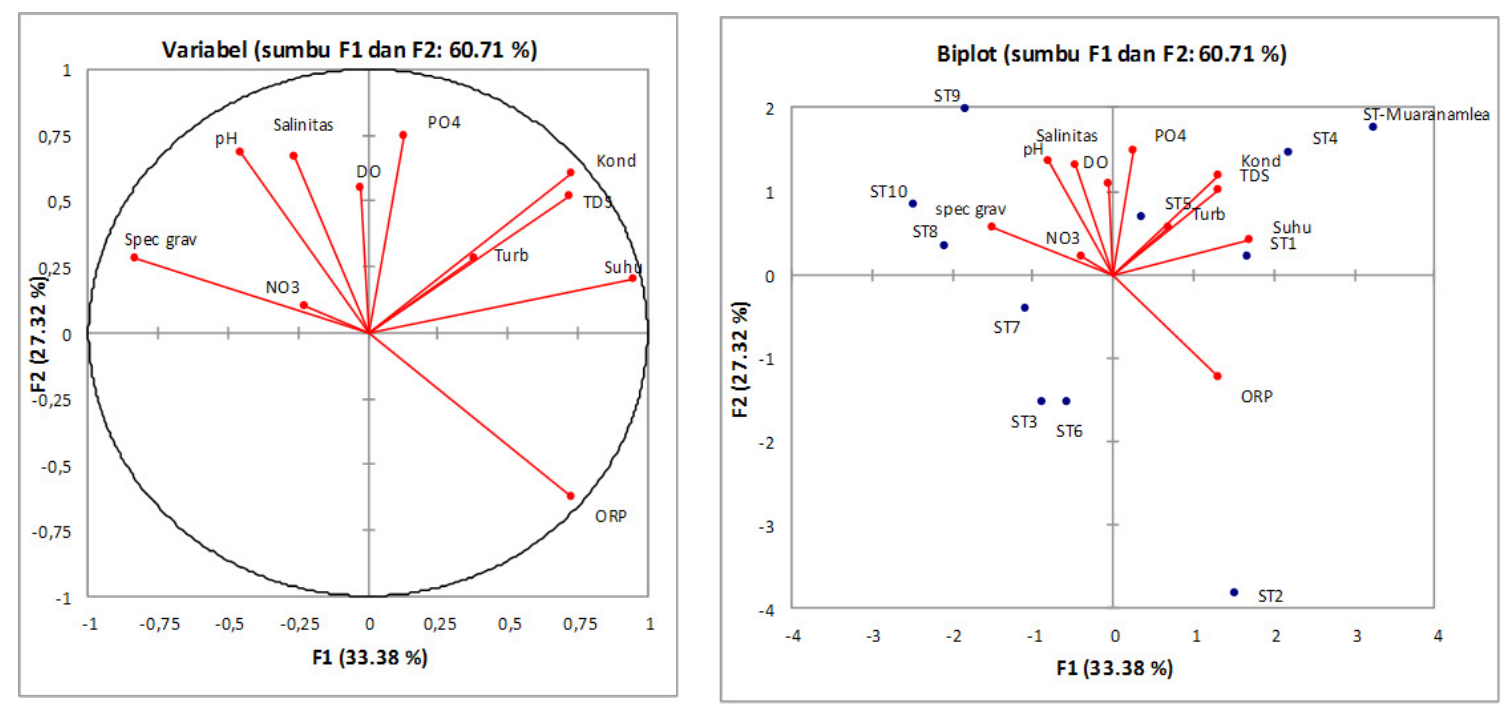

Gambar 5. Grafik analisis PCA karakteristik fisika kimia habitat perairan Teluk Kayeli. Panel ataskorelasi antar parameter fisika kimia pada sumbu 1 dan 2 (F1 X F2). Panel bawah biplot sebaran stasiun penelitian pada sumbu 1 dan 2 (F1 X F2). Keterangan: spec grav=specific gravity; Kond=Konduktivitas; DO=Dissolved Oxygen; TDS = Total Dissolved Solid; ORP = Oxidation Reduction Potential; $\mathrm{NO}_{3}=$ nitrat; $\mathrm{PO}_{4}=$ fosfat.

terukur yaitu suhu dan DO cukup sesuai sedangkan salinitas dan $\mathrm{pH}$ sangat sesuai untuk budi daya ikan laut dalam KJA (Tabel 3).

Berdasarkan analisis semua parameter baik secara deskriptif maupun PCA lokasi Teluk Kayeli sesuai dengan baku mutu (Tabel 1) baik untuk biota air laut atau sebagai destinasi wisata bahari. Namun perlu diperhitungkan pengukuran lainnya seperti batimetri perairan dan kondisi arus serta pemandangan seperti adanya pantai berpasir putih. Keberadaan lokasi penelitian di teluk sudah sesuai untuk melakukan budi daya baik KJA maupun budi daya rumput laut. Hal ini seperti yang dilakukan Radiarta et al. (2006) di Teluk Kapontori, Sultenggara; Purnawan et al. (2015) di pulau Simeuleu, Murtiono et al. (2016) di perairan Teluk Ambon Dalam dan Anggraini et al. (2018) di perairan Pulau Tegal, Teluk Lampung. Penelitian terbaru di Teluk Kayeli dilakukan oleh Wamnebo et al. (2018) yang mengatakan bahwa ekosistem mangrove di teluk Kayeli masih sesuai untuk melakukan budi daya kepiting (sylvofishery).

Kesesuaian teluk Kayeli sebagai wisata bahari dalam penelitian ini berdasarkan kualitas perairan yang terukur masih sesuai dengan baku mutu yang ada. Namun untuk lokasi lahan yang sesuai masih diperlukan penelitian lebih lanjut terutama terkait dengan keindahan pantai, batimetri perairan dan infrstruktur yang mendukung. Diketahui di pulau Buru salah satu daerah destinasi wisata bahari adalah Pantai Jikumerasa yang memiliki pantai landai dengan pasir putih dan perairan jernih. Sedangkan daerah destinasi wisata yang terdapat di teluk Kayeli ada Pantai Merah Putih dan wisata hutan mangrove Teluk Kayeli (Pemda Kab Buru, 2019).

\section{Implikasi Penambangan dan Perikanan di Teluk Kayeli}

Pulau Buru sejak tahun 2011 ramai dengan adanya penambangan emas illegal terutama di Gunung Botak. Aktivitas penambangan ini memberikan dampak negatif

Tabel 3. Nilai indeks keanekaragaman, keseragaman dan dominansi fitoplankton dan zooplankton di Teluk Kayeli Oktober 2014

\begin{tabular}{llllll}
\hline Parameter & $\begin{array}{l}\text { Sangat } \\
\text { Sesuai } \\
\text { (S1) }\end{array}$ & $\begin{array}{l}\text { Cukup } \\
\text { Sesuai } \\
\text { (S2) }\end{array}$ & $\begin{array}{l}\text { Sesuai } \\
\text { bersyarat } \\
\text { (S3) }\end{array}$ & $\begin{array}{l}\text { Tidak sesuai } \\
\text { (N) }\end{array}$ & $\begin{array}{l}\text { Hasil } \\
\text { pengukuran }\end{array}$ \\
\hline Suhu perairan $\left({ }^{\circ} \mathrm{C}\right)$ & $28-32$ & $25-28$ & $20-25$ & $<25 \&>35$ & 27,505 \\
Salinitas (PSU/ppt) & $31-35$ & $28-31$ & $25-28$ & $<25 \&>35$ & 33,255 \\
Derajat keasaman $(\mathrm{pH})$ & $>7$ & $6-7$ & $4-6$ & $<4$ & 7,958 \\
Oksigen terlarut/DO $(\mathrm{mg} / \mathrm{L})$ & $>7$ & $5-7$ & $3-5$ & $<3$ & 5,89 \\
Nitrat $(\mathrm{mg} / \mathrm{L})$ & $0,9-3,19$ & $0,69-0,89$ & $3,2-3,39$ & $\leq 0,7$ dan $\geq 3,4$ & 0,006 \\
Fosfat $(\mathrm{mg} / \mathrm{L})$ & $\geq 0,2 \leq 0,5$ & $\geq 0,5-0,7$ & $<0,2$ dan $>0,8$ & & 0,005
\end{tabular}



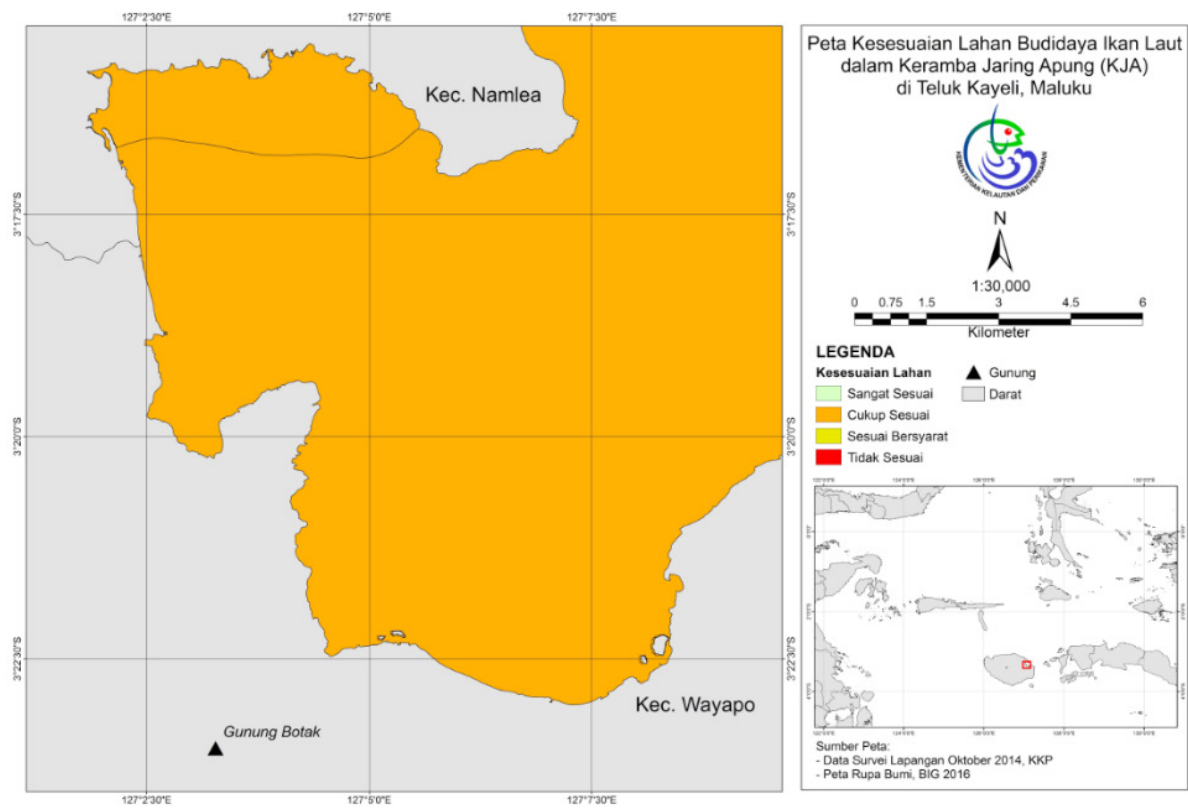

Gambar 6. Peta Kesesuain lahan Keramba Jaring Apung .

bagi kehidupan sosial dan ekonomi masyarakat pulau Buru (Hasyimi et al, 2014). Hasil penelitian Male et al. (2014) dan Salatutin et al. (2015) kandungan merkuri pada biota kerang dan sedimen masih menunjukkan nilai di bawah ambang batas, namun telah terlihat adanya distribusi spasial kandungan merkuri di sedimen mulai dari hulu sampai ke hilir. Akibat terdistribusinya merkuri, maka kandungan merkuri di badan air (sungai sampai laut) dan di sedimen akan terus meningkat jika pertambangan terus berlanjut. Proses bioakumulasi dari logam berat ini dalam proses rantai makanan akan dapat mematikan biota-biota yang terpapar merkuri yang akhirnya akan berdampak pada perikanan dan kesehatan masyarakat. Oleh karena itu pakar lingkungan, Male (2018) menganjurkan masyarakat untuk tidak mengkonsumsi bagian kepala dan tulang ikan dari perairan teluk Kayeli.

\section{KESIMPULAN}

Kualitas perairan Teluk Kayeli dalam kondisi baik dan sesuai dengan bakumutu yang dipergunakan untuk kehidupan biota laut (budi daya laut) maupun wisata bahari. Kaitannya dengan alokasi Teluk Kayeli sebagai tempat budi daya baik KJA atau rumput laut masih masih memerlukan data dan informasi mengenai kondisi batimetri, logam berat dan kondisi pergerakan arus setiap musimnya. Kelayakan untuk wisata bahari perlu data terkait lokasi seperti estetika, faktor sosial seperti banyaknya wisatawan dan fasilitas terkait erat dengan daya dukung lokasi. Diperlukan pula analisis daya dukung berbasis ekosistem yang lestari dan berkelanjutan untuk aktivitas budi daya maupun wisata bahari.

\section{PERSANTUNAN}

Ucapan terimakasih kepada Pusat Penelitian dan Pengembangan Sumber daya Laut dan Pesisir, Balitbang Kelautan dan Perikanan, Kementerian Kelautan dan Perikanan, Bupati Kabupaten Buru, Kepala Dinas Kelautan Perikanan Kabupaten Buru, Kepala BAPPEDA Kabupaten Buru, Kepala Puslitbang Laut Dalam LIPI Ambon, rekan peneliti dan masyarakat.

\section{DAFTAR PUSTAKA}

Anggraini, D.R., Damai, A.A. \& Hasani, Q. (2018). Analisis Kesesuaian Perairan untuk Budi daya Ikan Kerapu Bebek (Cromileptes Altivelis) di Perairan Pulau Tegal, Teluk Lampung. eJurnal Rekayasa dan Teknologi Budi daya Peraiaran, 6(1), 719-728.

Affan, J.M. (2012). Identifikasi lokasi untuk pengembangan budi daya keramba jarring apung (KJA) berdasarkan factor lingkungan dan kualitas air di perairan pantai timur Bangka Tengah. Depik, 1(1), 78-85.

APHA. (2005). Standard methods for the examination of water and waste water. American Public Health Association, American Water Works Association, and Water Pollution Control Federation. 21 $1^{\text {th }}$ edition. Washington D.C. (US).

Blei. D. (2008). COS 424: Interacting with data. http:// www.cs.princeton.edu/courses/archive/spr08/ cos424/scribe_notes/0424.pdf. [12 Agustus2015] 
Edward \& Manik, J.M. (1987). Kandungan Zat Hara Fosfat di Teluk Ambon pada Musim Timur dan Musim Barat. Teluk Ambon, Biologi, Perikanan, Oseanografi dan Geologi (Soemodihardjo dkk Eds): 112-116.

Effendi, H. (2003). Telaah Kualitas Air bagi Pengolahan Sumber daya Hayati Lingkungan Perairan. Yogyakarta. Kanisius.

Horne, A.J. \& Goldman, C.R. (1983). Limnology. Mc. Graw Hill. International Book Company, Tokyo. 576 pp.

Hutagalung, H.P. \& Rozak, A. (1997). Metode Analisis Air Laut, Sedimen dan Biota. Buku 2. Pusat Penelitian dan Pengembangan Oseanologi. LIPI. Jakarta.

Illin, A. \& Raiko, T. (2010). Practical approaches to principal component analysis in the presence of missing values. Journal of Machine Learning Research, (11), 1957 - 2000.

Khow S. (2015). Teluk Kayeli terancam zat mercury Gunung Botak di Pulau Buru. http://malukunews. co/berita/buru/10ui14v5bzorg25vg [10 Agustus 2015].

KMNLH. (2004). Keputusan Menteri Negara Lingkungan Hidup Nomor 51 Tahun 2004 Tentang Baku Mutu Air Laut.

Lee, C.D., Wang S.B. \& Kao C.L. (1978). Benthic macroinvertebrate and fish as biological indicator of water quality with refference to community diversity index. In Quano E.A.R., Developing countries, The Asian Institute of Technology, London.

Legendre, L. \& Legendre, P. (1983). Statistical Ecology: A Primer on Method and Computing. Jhon Wiley and Sons.Inc. New York .337 p.

Mahida, U.N. (1986). Pencemaran Airdan Pemanfaatan Limbah Industri. C.V. Rajawali. Jakarta. 543 hal

Male, Y.T. (2014). Gubernur Maluku: Hentikan tambang emas ilegal. http://tataruangpertanahan.com/ kliping-712-gubernur-maluku-hentikan-tambangemas-ilegal.html [10 Agustus 2015]

Male, Y.T. (2018). Pakar ingatkan masyarakat jangan konsumsi kepala ikan. https://www. inews.id/daerah/regional/pakar-ingatkanmasyarakat-jangan-konsumsi-kepala-ikan-inialasannya/298842 [31 Desember 2018]
Male, Y.T., Nonlohy, A.Ch. \& Asriningsih. (2014). Analisis pendahuluan kadar merkuri $(\mathrm{Hg})$ pada beberapa jenis kerang. Ind. J. Chem. Res, 2, 136141

Mulyadi ,H.A \& Radjab, A.W. (2015). Dinamika Spasial Kelimpahan Zooplankton pada Musism Timur di Perairan Pesisir Morella, Maluku Tengah. Jurnal IImu dan Teknologi Kelautan Tropis, 7(1), 109122.

Murtiono, L.H., Yunianto, D. \& Nuraini, W. (2016) Analisis Kesesuaian Lahan Budi daya Kerapu System Keramba Jarring Apung dengan Aplikasi Aystem Informasi Geografisdi Perairan Teluk Ambon Dalam. Jurnal Teknologi Budi daya Laut , 6, 1-16.

Nybakken, J.W. (1992). Biologi Laut Suatu Pendekatan Ekologi. Penerjemah: M. Eidman, Koesoebiono, D.G. Bangen, M. Hutomo dan S. Sukarjo. Jakarta. Gramedia : 459 hal.

Papalia, S. (2013). The studies of seaweed distribution and diversity in Kayeli Bay and Jikumerasa water, Buru Island, Moluucas Province. Prosiding F MIPA Universitas Pattimura.

Pemda Kab. Buru (2014). Kondisi Geografi http:// burukab.go.id/ [12 November 2014]

Pemda Kab Buru. (2019). Objek Wisata http://burukab. go.id/index.php/objek-wisata/ [25 Maret 2019]

Pescod, M.B. (1978). Enviromental Indices Theory and Prestise. Ann Arbour Science Inc. Michigan. 59 hal.

Purnawan, S., Zaki, M., Asnawi, T.M. \& Setiawan, I. (2015). Studi Penentuan Lokasi Budi daya Kerapu Menggunakan Keramba Jaring Apung di Peraiaran Timur Simeuleu. Depik. 4(1), 40-48. DOI: http://dx.doi.org/10.13170/depik.1.1.2365

Radiarta, I.N., Prihadi, T.H., Saputra A., Hariyadi, J. \& Johan, O. (2006). Penentuan Lokasi Budi daya Ikan KJA Menggunakan Analisis Multikriteria dengan SIG di Teluk Kapontori, Sultenggara. Jurnal Riset Akuakultur, 1(3), 303-318.

Romimohtarto, K. (1985). Kualitas air dalam budi daya laut. Seafarming Workshop Repot, 28 Oktober 1 November 1985. Bandar Lampung. http://www. fao.org/docrep/field/003/ab882e/ab882e13.htm [20 November 2012]

Rustam, A., Yulius., Ramdhan, M. Salim H. L., Purbani D. \& Arifin, T. ( 2014), Analisis Kualitas Perairan 
Kaitannya Dengan Keberlanjutan Ekosistem Untuk Kawasan budi daya perikanan Di Kawasan Pulau Wangi-Wangi, Kabupaten Wakatobi, Prosiding PIT ISOI-X, Ikatan Sarjana Oseanologi Indonesia, Jakarta

Sahu, G., Satpathy, K., Mohanty, A. \& Sarkar, S. (2012). Variations in Community Structure of Phytoplankton in Relation to Physicochemical Properties of Coastal Waters, Southeast Coast of India. Indian J. Geo Mar. Sci. 41(3), 223-241.

Salatutin, F.M., Batawi, C.Y., Lessil, C.Y. \& Male, Y.T. (2015) Analisis Sebaran Merkuri (Hg) pada Area Irigasi Sungai Waeapo, Kab. Buru, ProvinsMaluku Akibat Penambangan Emas Tanpa ljin di Areal Gunung Botak. Ind. J. Chem. Res, 3, 270-276

Sanusi, H. (2006). Kimia Laut, Proses Fisik Kimia dan Interaksinya dengan Lingkungan. Departemen IImu dan Teknologi Kelautan. Fakultas Perkanan dan IImu Kelautan. Institut Pertanian Bogor.

Setiawan, A. (2012). Densitas air laut. http://oseanografi. blogspot.com/2005/07/densitas-air-laut.html [17 November 2012]

Siwalima (2015). Ikan Teluk Kayeli mati tercemar limbah air raksa. http://www.siwalimanews.com/ post/ikan_teluk_kayeli_mati_tercemar_limbah_ air_raksa [10 Agustus 2015]

Sukma, W.A, B. Seno, A.N., S. Nurjanah \&. Syakur, A. (2013). Peningkatan kualitas air pantai menjadi air bersih dengan penerapan teknologi plasma non-thermal dan multi step filter. DIPA IPTEKS, I(1), 20-24.

Urbasa, P.A., Undap, S.L. \& Rompas, R.J. (2015). Dampak Kualitas Air pada Budi daya Ikan dengan Jaring Tancap di Desa Toulimembet Danau Tondano. Jurnal Budi daya Perairan, 3(1), 59-67.

Wamnebo, M.I., Karim, M.Y., Syamsuddin, R. \& Yunus, B. (2018). Bio-physicochemical Analysis of Mangrove Area of Kayeli Bay, Buru Regency, Maluku Province, Indonesia for The Development of Mud Crab Scylla sp. Culture With Silvofishery System. AACL Bioflux, 11(4), 1130-1135.

Welch. E.B. (1980). Ecological effect of waste water. Cambridge University Press. Cambridge. 337p.

Wouthuyzen, S., Supriadi, H.I. \& Pulumahuny, F.S. (2002). Pemantauan Evaluasi dan Pengelolaan Sumber daya Mangrove di Wilayah Pesisir Teluk Kotania dan Teluk Kayeli, Maluku Tengah Menggunakan Multi-temporal Data Citra Satelit
Landsat. Prosiding Seminar Nasional Limnologi 2002. ISBN979-8163. 211-224

Yamaji, I. (1966). Illustration of marine plankton of Japan. Osaka (Japan): Hoikusha Publishin Co. Ltd.

Yuliana. (2014). Keterkaitan antara kelimpahan zooplankton dengan fitoplankton dan parameter fisika-kimia di perairan Jailolo, Halmahera Barat. Maspari Journal, 1(6), 25-31. 
